PNL-3629

UC-62

\title{
Alternate Protection Concepts For Second Surface Silver/ Glass Solar Mirrors
}

\author{
C. Q Buckwalter \\ L. S. Dake \\ J. S. Hartman \\ M. A. Lind
}

October 1980

Prepared for

Sandia National Laboratories

Livermore, California

under Related Services Agreement 300A01406

and the U.S. Department of Energy

under Contract DE-AC06-76RLO 1830 


\title{
NOTICE
}

This report was prepared as an account of work sponsored by the United States Government. Neither the United States nor the Department of Energy, nor any of their employees, nor any of their contractors, subcontractors, or their employees, makes any warranty, express or implied, or assumes any legal liability or responsibility for the accuracy, completeness or usefulness of any information, apparatus, product or process disclosed, or represents that its use would not infringe privately owned rights.

The views, opinions and conclusions contained in this report are those of the contractor and do not necessarily represent those of the United States Government or the United States Department of Energy.

\author{
PACIFIC NORTHWEST LABORATORY \\ operated by \\ BATTELLE \\ for the \\ UNITED STATES DEPARTMENT OF ENERGY \\ Under Contract DE-AC06-76RLO 1830
}

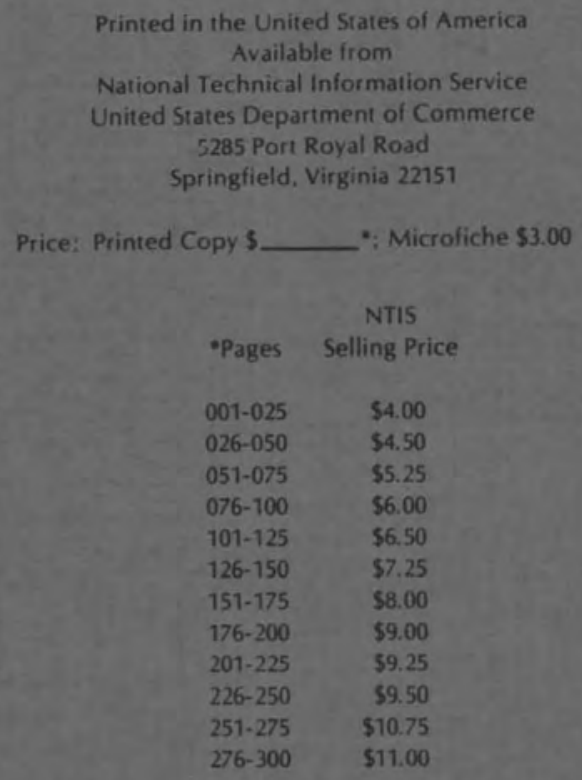




\title{
33679000561615
}

\section{ALTERNATE PROTECTION CONCEPTS \\ FOR SECOND SURFACE SILVER/GLASS \\ SOLAR MIRRORS}

\author{
C. Q. Buckwal ter \\ L. S. Dake \\ J. S. Hartman \\ M. A. Lind
}

October 1980

Prepared for

Sandia National Laboratories

Livermore, California

under Related Services Agreement 300A01406

and the U.S. Department of Energy

under Contract DE-AC06-76RLO 1830

Pacific Northwest Laboratory

Richland, Washington 99352 


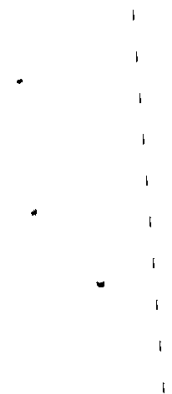

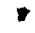




\section{FOREWORD}

This report is the result of technical analysis performed for Sandia National Laboratories and authorized under Sandia Livermore Laboratories Federal Agency Order 92-8522 in support of the U.S. Department of Energy Solar Thermal Large Power Systems Project. The purpose of the work reported here was to provide a preliminary examination of the feasibility of improving the durability and life expectancy of second surface silver/glass solar mirrors by the application of impermeable protective coatings. This report documents the early Pacific Northwest Laboratory results in three areas; solder glass laminates, liquid $\mathrm{SiO}_{2}$ and $\mathrm{TiO}_{2}$ overcoats, and electroless nickel overcoats. 


\section{ACKNOWLEDGEMENTS}

The authors wish to express their appreciation to T. Stewart, M. Nordmeyer, D. Nelson and $\mathrm{K}$. Welsch for their assistance in sample preparation and testing. 


\section{SUMMARY AND CONCLUSIONS}

Preliminary investigations into three technologies having the potential of significantly enhancing the durability of solar mirrors are reported. The approaches discussed are based on the assumption that sealing the silver layer on second surface mirrors from the external environment with protective overcoats will significantly extend their useful field service life. Considered here are: 1) edge sealing a second sheet of glass over the silver layer using solder glasses, 2) overcoating the silver layer with liquid applied $\mathrm{SiO}_{2}$ or $\mathrm{TiO}_{2}$ coatings, and 3) overcoating the silver layer with an electroless nickel film.

Preliminary experiments were performed using $\mathrm{Sb}_{2} \mathrm{O}_{5}-\mathrm{K}_{2} \mathrm{O}$ and $\mathrm{PbO}$ based solder glasses to edge sea 1 a second sheet of glass over the silver mirror surface in a laminate structure. Problems encountered in the formulation of the $\mathrm{Sb}_{2} \mathrm{O}_{5}-\mathrm{K}_{2} \mathrm{O}$ glasses forced abandonment of these low melting point solder glass experiments in favor of the higher melting point $\mathrm{PbO}$ based solder glasses. Unfortunately materials compatibility problems were encountered when using several of the commercially available Pbo based solder glasses alternatives.

A cursory evaluation of liquid $\mathrm{SiO}_{2}$ and $\mathrm{TiO}_{2}$ coatings available from one commercial manufacturer was also undertaken. The films were applied as direct overcoats on both silver only and silver/copper mirror substrates. Although the process appeared to yield visually acceptable coatings, under microscopic examination the films were found to be porous and pinhole riddled after the final curing step. Consequently, they did not stand up well to salt spray and $\mathrm{HCl}$ vapor tests. Modification of the solution chemistry will be required to enhance the coating compatibility for silver mirrors.

Background data was collected in an investigation of the feasibility of overcoating the silver or silver/copper mirrors with an electroless deposited nickel film. Two different formulations, one a basic solution, the other a commercial acidic solution, were attempted. Both chemistries claim tough, durable films which will resist environmental attack. Film integrity problems 
were encountered for fairly thick films in the feasibility experiments attempted. Nevertheless, the concept appears sound and merits further investigation. 


\section{CONTENTS}

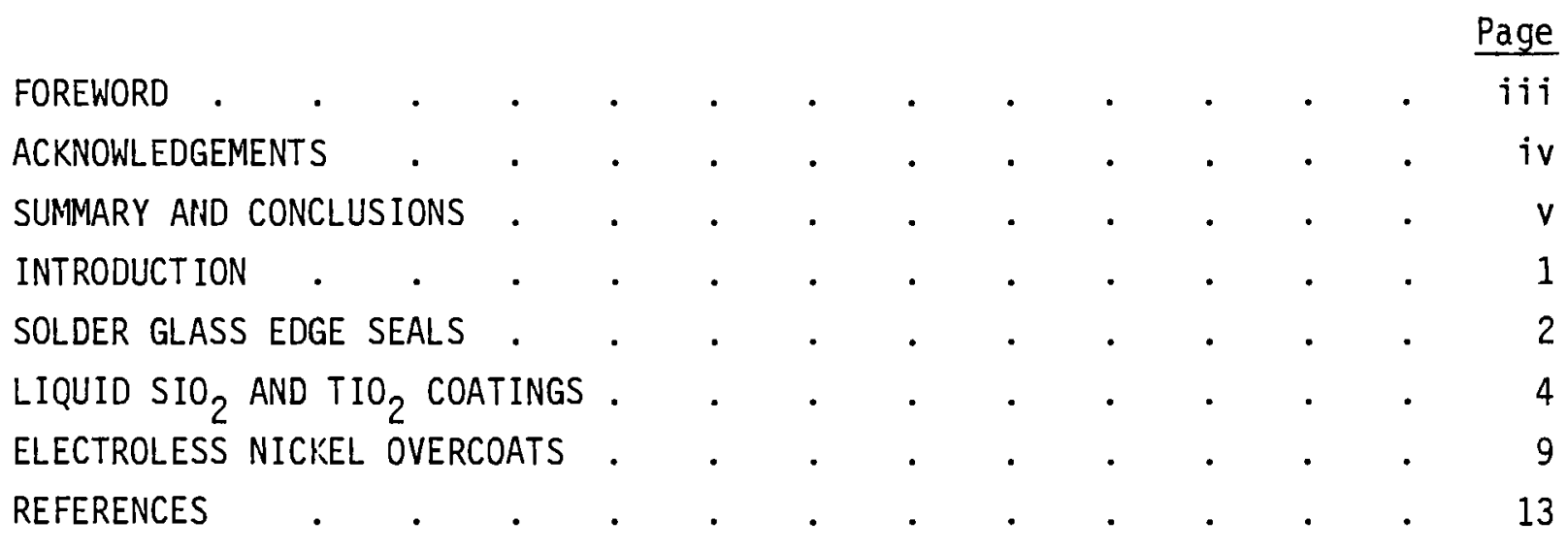




\section{LIST OF FIGURES}

Figure

1. Schematic Diagram of Solder Glass Edge

Sealed Laminated Mirror . . .

Page

2. 400X Darkfield Micrograph of Silver Mirror Surface
3. Pinholes and Surface Cracking Observed in the $\mathrm{TiO}_{2}$
Overcoated Silver Mirrors after the Final 2-1/2 Minute $400^{\circ} \mathrm{C}$ Bake 


\section{INTRODUCTION}

The problems associated with the degradation of second surface silver/ glass solar heliostat mirrors have been well documented over the last several years. (1-3) Although the precise causes, mechanisms and kinetics of the degradation processes are still speculative, the single identified common denominator associated with the observed corrosion is the presence of standing water on the back of the mirror. If in fact liquid water is a major factor in limiting the useful life of the mirror, exclusion of that water from the silver layer may significantly extend the operating life of field service mirrors.

The current commercial chemically silvered mirror technology uses a thin copper layer overcoated with paint to protect the silver layer. The details of the mirroring process are discussed el sewhere. (2) It suffices to say that the paint layer commonly used is relatively permeable to water. In heliostat structures where water can accumulate, it may act as a vehicle or a primary reactant for the degradation phenomena. A less permeable membrane could prevent the water from interacting with the silver layer and thus prolong the mirror life.

Prel iminary investigations of three approaches for forming an impermeable barrier are reported here. These approaches are 1) placing a second sheet of glass over the silver side of the mirror and sealing the edges of the laminate with a solder glass; 2) overcoating the silver layer with a thin coating of a solgel metal oxide; and 3) overcoating the silver layer with a thin coating of electroless nickel. These techniques were chosen for experimentation primarily because they may be (at least conceptual1y) adapted directly to the current mirror production lines with minimum modification and because they may be relatively low in cost when compared with the more proven alternatives such as PVB autoclaved laminates. 


\section{SOLDER GLASS EDGE SEALS}

Encapsulation of the silver layer between two sheets of glass is one method of preventing moisture penetration provided sufficiently impermeable edge seals can be found. Glass and ceramic compounds are good candidates if they can be formed into edge seals. Low melting point glasses, usually referred to as solder glasses, have been used by the TV picture tube industry for many years to provide vacuum-tight seals between two sections of the tube. If this technology could be adapted to solar mirror laminates to provide an effective edge seal, the moisture penetration concerns would be eliminated.

There are two primary considerations that must be factored into the solder glass edge seal concept. One involves thermal expansion compatibility with the glasses to be sealed. The other involves the thermal stability and the chemical compatibility of the silver mirror layer to be encapsulated.

Ideally, the thermal expansion coefficients of the solder glass and the laminated glass should be identical. A typical expansion coefficient for soda-lime silicate glass is $74 \times 10^{-7}{ }^{\circ} \mathrm{C}^{-1}$. Since matching the expansion coefficient of the soda-lime silicate with common solder glasses is not practical, it is desirable to minimize the temperature excursions encountered by the glass during processing (i.e., use very low melting point solder glasses). In addition, high temperatures $\left(>300^{\circ} \mathrm{C}\right)$ even for relatively short time periods (minutes) may lead to severe agglomeration or oxidation of the silver layer unless the mirror is surrounded by an inert atmosphere. ${ }^{(4)}$

Preliminary experiments at PNL explored the use of antimony oxidepotassium oxide solder glasses. Although the coefficient of thermal expansion for the antimony oxide based glasses is larger ( $\sim 1.4 X)$ than for soda-lime silicate glasses, the low softening temperature $\left(250^{\circ} \mathrm{C}\right)^{(5)}$ is attractive even though a possible sealing temperature of $100^{\circ} \mathrm{C}-150^{\circ} \mathrm{C}$ higher might be expected. Unfortunately, these glasses were not commercially available and attempts to formulate them in the laboratory were unsuccessful. 
Two commercial vendors (Mobay Chemical Corporation and Corning Glass Works) that supply lead oxide based solder glasses were contacted. These glasses are formulated with a range of expansion coefficients $\left(42 \times 10^{-7}{ }^{\circ} \mathrm{C}^{-1}\right.$ $\left.89 \times 10^{-7}{ }^{\circ} \mathrm{C}^{-1}\right)$ and sealing temperatures $\left(440^{\circ} \mathrm{C}-750^{\circ} \mathrm{C}\right)$. Several mirror laminate samples were prepared using these glasses.

The construction of the laminate samples is shown in Figure 1. The soda-lime silicate glass was chemically silvered. Some samples were silvered only; others were both silver and copper coated. None of the test samples were painted. A small $(\sim 1 \mathrm{~cm})$ band of the metalized layer was removed around the edge of the test coupon. The solder glasses were mixed into a slurry using amyl acetate as the solvent vehicle and applied to the stripped regions around the edge of the coupon. A second piece of soda-lime silicate glass was then fit over the mirror. The sample was placed in an argon-filled tube furnace and heated for the time and temperature recommended by the manufacturer.

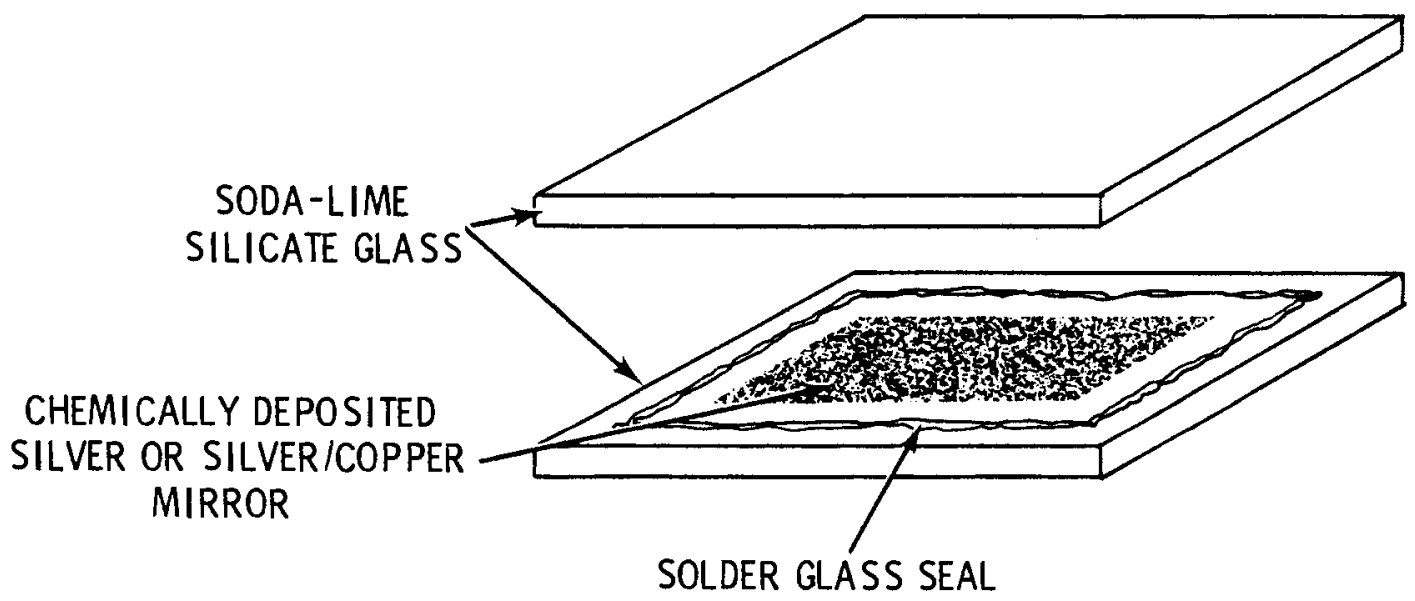

FIGURE 1. Schematic Diagram of Solder Glass Edge Sealed Laminated Mirror 
Although the samples sealed, there were several complications. For the silver only mirrors, the silver layer appeared to oxidize and turn nearly transparent. The silver/copper overcoated mirrors showed different characteristics. The silver layer remained visually intact as did most of the copper overcoat. However, the reduction of the lead in the solder glass was much more noticeable than in the silver only mirror. The solder glass turned an opaque gray indicating possible reduction to the base metal.

The integrity and the durability of these solder glass seals were not tested. Although lead-oxide-based glasses are not noted for their durability, the geometry of the seal reduces the durability requirements of the seal considerably.

In summary, the experiments indicate that there may be some fundamental problems associated with the application of the lead-based solder glasses. It is possible that controlled local heating around the edge of the mirror might alleviate these problems, but more research is necessary to draw firm conclusions regarding the feasibility of this technology for sealed mirror applications.

\section{$\underline{\text { LIQUID SIO }}_{2}$ AND TIO 2 COATINGS}

A 1 imited investigation of commercial liquid based silicon dioxide and titanium dioxide protective films was initiated to determine if they could be used to protect silver mirrors from chemical attack and degradation. The 1 iquid chemistry was supplied by E. Merck, Darmstadt, West Germany through distributors in the United States. Although only limited technical data was available from the manufacturer, the claim is made that the process is capable of yielding tough, thin, pinhole-free films on some substrate materials.

The oxide films are formed after the deposition of an organometallic liquid coating and the subsequent evaporation of the carrier solvent (proprietary composition). The actual deposition process recommended by the manufacturer involves spraying, curtain coating, dipping or spinning the solution onto the surface to be coated followed by three heating steps. The first 
bake is a 5 -min predry at $60-80^{\circ} \mathrm{C}$. The film is then hardened (the solvent driven off) $5-10 \mathrm{~min}$ at $200^{\circ} \mathrm{C}$ and then baked (presumably to densify the coating) for $5-10 \mathrm{~min}$ at $450-500^{\circ} \mathrm{C}$.

The experiments performed in this investigation addressed several concerns regarding the applicability of the films for solar mirrors. First, it is necessary to know if silver or silver/copper overcoated mirrors capable of withstanding the high processing temperatures required to densify the films without significant degradation due to agglomeration of the silver. Second, verification that the films applied as recommended or with slight variations actually form nonporous, pinhole-free coatings over the silver and copper metalized substrates is required. The major concern is the performance of these oxide coated mirrors compared to the traditional paint coated mirrors in durability tests.

All the samples discussed here were prepared in an identical fashion except for varying the time of the final heat treatment. The soda-lime silicate glass substrates were silvered in the traditional manner ${ }^{(2)}$ and dried in a $100^{\circ} \mathrm{C}$ oven for $5 \mathrm{~min}$ to remove any residual moisture. Both silver only and silver/copper mirror samples were prepared.

The liquid $\mathrm{SiO}_{2}$ or $\mathrm{TiO}_{2}$ solution was applied using a spin-on technique recommended by the manufacturer. A $6000 \mathrm{rpm}$ centrifuge was modified to accept a single $15 \mathrm{~cm}$ ( 6 in.) square sample centered on the axis of rotation. A small quantity ( $\sim c c$ ) of the liquid was dropped onto the center of the cleaned rotating substrate. The liquid flowed to the outside leaving a visually uniform coating on the sample. The film thickness as measured by an optical angstrometer varied from about 0.2 to 0.4 microns depending on the amount of thinning solution used.

Most of the samples survived the $10-\mathrm{min}, 200^{\circ} \mathrm{C}$ bake cycle in atmosphere that is used to drive off the solvent and harden the coating. There was little or no visual degradation of the silver at this point. However, no optical spectra were run to detect agglomeration or silver colloid formation. Microscopic examination at $400 x$ revealed no evidence of agglomeration. 
In the early attempts, the silver only $\mathrm{SiO}_{2}$ overcoated mirrors degraded rapidly in the $10-\mathrm{min}, 500^{\circ} \mathrm{C}$ bake. Therefore, the temperature was reduced to $400^{\circ} \mathrm{C}$ and samples were baked for 2.5, 5, 7.5 and 10 minutes. Visually, the 2.5 and 5 min samples showed no hazing or oxidation. However, observation at $400 \mathrm{X}$ using a darkfield reflecting microscope revealed numerous small pinholes in the $\mathrm{SiO}_{2}$ and silver layers. The pinholes increased in density and size with increasing baking time.

The left side of Figure 2 shows a $400 x$ micrograph of a silver only mirror prior to application of the $\mathrm{SiO}_{2}$ overcoat. Numerous small pinholes are present. In a transmitted light photograph at this magnification, the holes are barely visible. The photograph is slightly overexposed; therefore the holes appear larger than they actually are. The right side of the figure shows the $\mathrm{SiO}_{2}$ overcoated mirror after the $5-\mathrm{min}, 400^{\circ} \mathrm{C}$ bake. The pinhole density of the 2.5 min mirror was about half of that for the 5 min mirror. The size of the pinholes in the photograph appear the same in the transmitted and darkfield reflected images and are much larger and more numerous than the pinholes prior to baking.

The copper-coated silver mirrors showed slightly different characteristics. After the high temperature bake the characteristic copper color of the mirror was nearly gone on most of the samples and the mirror back looked silver. Only the mirrors baked 2.5 min remained copper colored. Again pinholes were found on the mirrors baked for $5-10 \mathrm{~min}$ at $400^{\circ} \mathrm{C}$. There appeared to be no pinholes on about half of the mirrors baked for only 2.5 min.

The $\mathrm{TiO}_{2}$ overcoated mirrors produced fared worse than the $\mathrm{SiO}_{2}$ overcoated mirrors. In addition to pinhole formation, a network of cracks developed in the coating. Figure 3 shows a typical $400 \mathrm{X}$ micrograph of a mirror baked at $400^{\circ} \mathrm{C}$ for $2.5 \mathrm{~min}$.

Salt spray and $\mathrm{HCl}$ vapor tests which are good indicators of protective coating permeability when used on silvered mirrors were performed on the $\mathrm{SiO}_{2}$ overcoated mirrors. Most of these mirrors degraded nearly as rapidly as bare silver mirrors while the 2.5 min final bake mirror lasted $50 \%$ longer than the uncoated mirrors. The vapor tests thus verified the lack of protection offered by the coatings. 


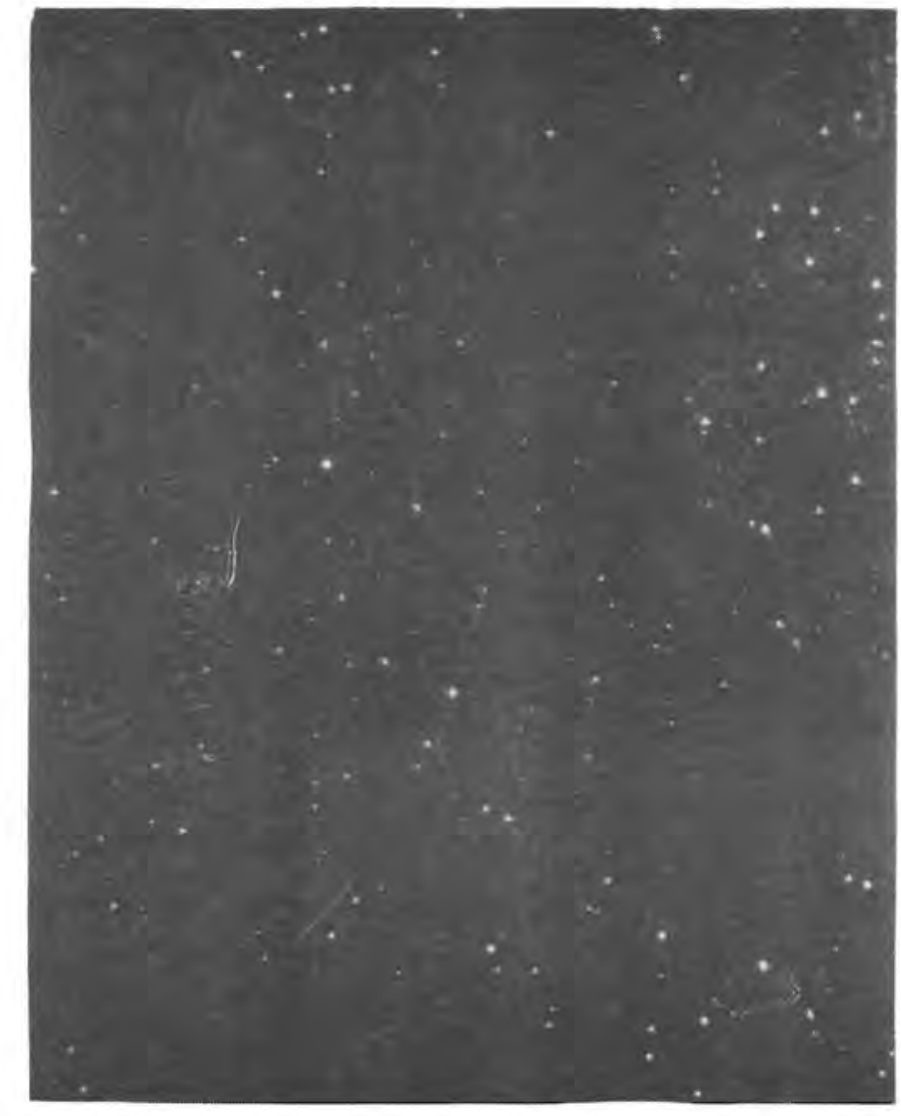

(a)
Ag COATING PRIOR TO $\mathrm{SiO}_{2}$ OVERCOAT

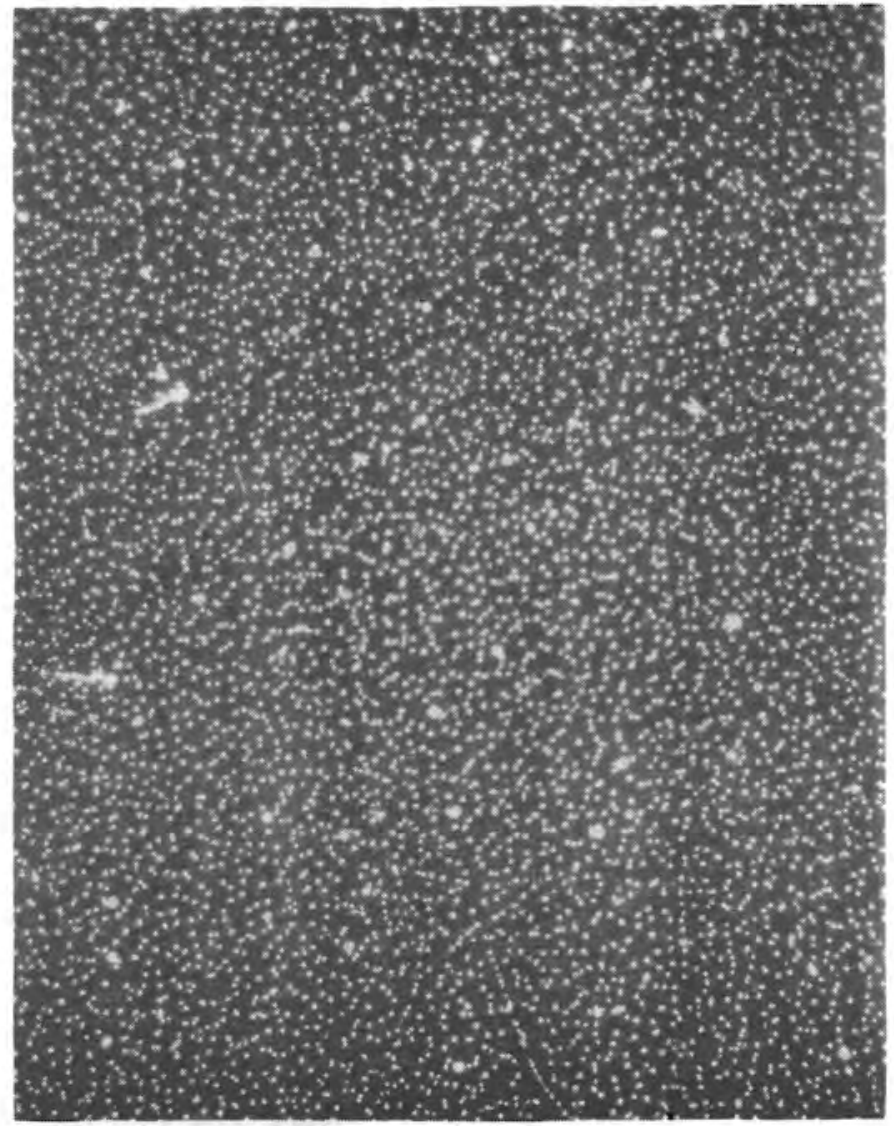

(b)

$\mathrm{SiO}_{2}$ OVER Ag AFTER 5 min BAKE @ $450^{\circ} \mathrm{C}$

FIGURE 2. $400 x$ Darkfield Micrograph of Silver Mirror Surface (a) Prior to $\mathrm{SiO}_{2}$ Overcoat and b) After $\mathrm{SiO}_{2}$ Overcoat is Baked 


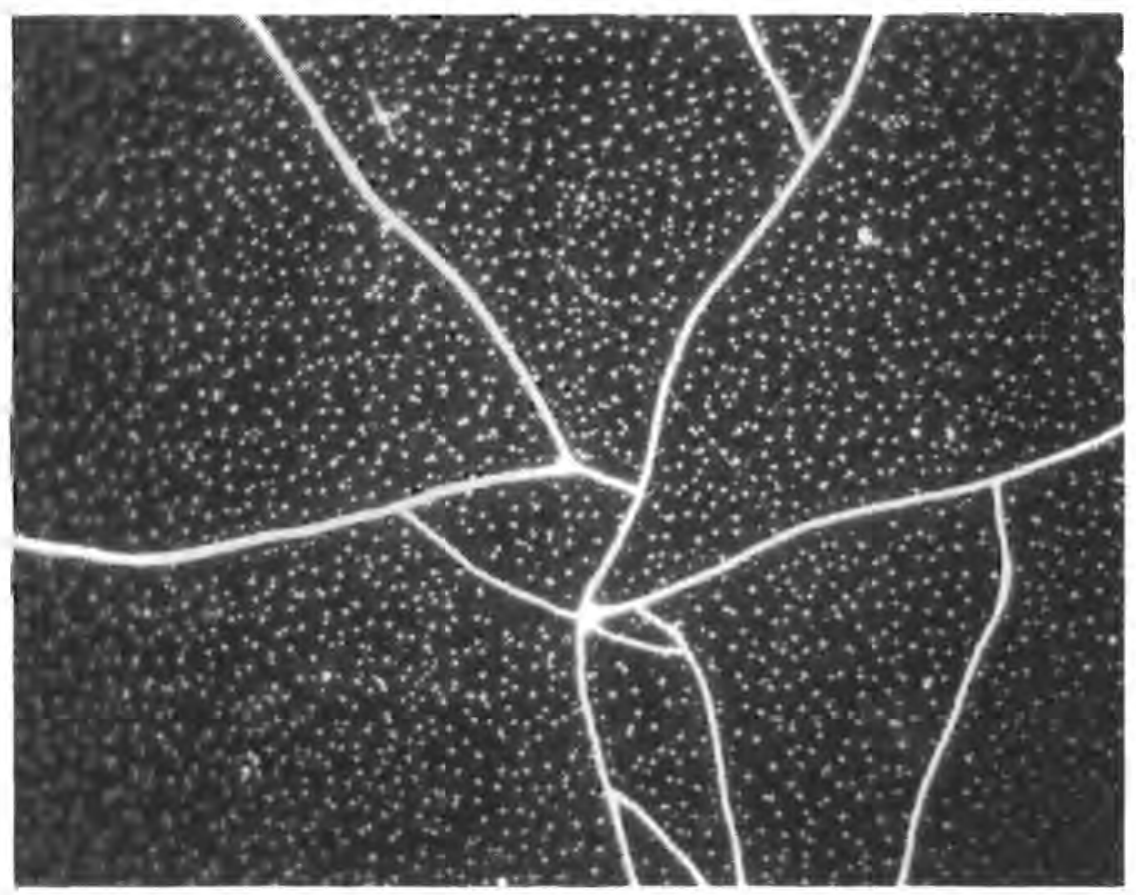

FIGURE 3. Pinholes and Surface Cracking Observed in the $\mathrm{TiO}_{2}$ Overcoated Silver Mirrors after the final $2-1 / 2$ minute $400^{\circ} \mathrm{C}$ Bake

Attempts were made to apply a second coating of $\mathrm{SiO}_{2}$ over the first in hopes of filling the pinholes. In general, the double overcoat was ineffective when applied on top of a high temperature baked first coat.

Time and available resources did not allow further experimentation with processing parameters. Thicker coatings applied by multiple overcoating prior to the first bake were not attempted. No attempt was made to bake the coatings in an inert atmosphere. If silver agglomeration is responsible for the pinhole formation in the films, then placing the mirrors in an oxygenfree atmosphere during the high temperature cures may inhibit the agglomeration $(4,6)$ and the subsequent pinhole formation. 
While the limited experiments reported here did not produce the dense, pinhole-free coatings on silver only or silver copper substrates that were desired, it is not clear that they are incapable of doing so. These experiments were designed to perform a limited assessment of only one commercial coating, not test the generic value of the solgel concept. It is likely that solgel coatings can be formulated that densify at significantly lower temperatures $\left(250-300^{\circ} \mathrm{C}\right)$. If the coatings can be densified without the formation of pinholes, they may provide the inexpensive $\left(\sim \$ 0.50 / \mathrm{m}^{2}\right)$, durable, impermeable coating required to significantly increase the life expectancy of solar mirrors.

\section{ELECTROLESS NICKEL OVERCOATS}

Mirror lifetime might also be extended if the final metallic coating applied to the mirror during production would provide good corrosion resistance and negligible permeability. Such a layer might isolate the vulnerable silver layer between two stable barriers and prevent access by some of the environmental stresses responsible for degradation. Thin nickel coatings prepared with an electroless process are one candidate. Nickel is attractive because of its corrosion resistance, wear resistance and hardness. The electroless deposition process is conceptually compatible with the conventional wet chemistry mirror production process and yields coatings with low porosity and good film uniformity.

Electroless nickel technology has received considerable attention since the first deposition using hypophosphite reduction nickel was reported in 1946. $(7,8)$ The processes developed since that time have been applied to metals, glass and other dielectrics, and plastic substrates. The electroless nickel films are used on many components of moving mechanical systems because of their hardness and corrosion resistance. Film thicknesses used for mechanical system components range from 4-50 $\mu \mathrm{m}$ to insure long service lifetime but thinner films may be feasible. Plating is conventionally performed by component submersion in dip tanks using a single solution rather than with a spray-on process because the desired film thicknesses are readily obtained more quickly. 
A variety of electroless nickel solutions are available (open literature and proprietary formulations) that allow the use of either acidic ( $\mathrm{pH} 4-7$ ) or basic (pH 8-11) baths. $(9,10)$ The reaction is autocatalytic and deposition does not begin until the solutions are exposed to an active surface. This allows the solutions to be premixed and stored without the deposition reaction occurring. This is in contrast to the commercial silver and copper solutions which are maintained as separate components and the deposition process begins only when the solutions are mixed. ${ }^{(2)}$ Most electroless nickel solutions are used at elevated temperatures $\left(80-90^{\circ} \mathrm{C}\right)$ to achieve the desired deposition rates.

The films deposited by the electroless processes are mixtures of nickel and phosphorus. The phosphorus content has been found to decrease as the pH of the solution is increased $(11,12)$ with the range of phosphorus content being $23-12 w t . \%$. (13) The unannealed films are a solid solution of phosphorus in a very fine polycrystalline nickel system. ${ }^{(14)}$ No evidence has been noted of phosphorus segregation to large grain boundaries during deposition with the associated potential for grain boundary penetration by environmental contaminates. Heat treatment of the films converts them to a mixture of $\mathrm{Ni}_{3} \mathrm{P}$ and nickel. (15)

The film nucleation and growth processes on many substrates are very similar to those seen in the wet chemistry silver deposition process for mirror production. Glass substrates must be pre-treated with stannous chloride or palladium chloride solutions to sensitize and activate the surface before application of the nickel solutions. (11) This allows the initial nickel crystallization which then propogates the autocatalytic reaction. Film growth on these substrates begins at discrete active sites on the surface and progresses with the growth of hemispherical islands. (16) However, film growth on naturally active surfaces proceeds as uniform film growth without the presence of island structure. (16) Experience with copper substrates is not completely clear. Brown and Jarrett $(10)$ indicate that copper alloy surfaces must be pretreated with palladium chloride while Graham et al. (17) prepared films on copper with no mention of surface activation. 
The different growth regimes may allow the use of a mirror structure that would facilitate the growth of a uniform thin nickel overcoat for improved environmental stability.

The deposition rate for most electroless nickel baths are fairly slow compared to those for the mirror industry silver and copper processes. These nickel growth rates and the standard commercial coating thicknesses of 5-50 $\mathrm{mm}$ have dictated the use of dip tanks for film deposition. But the application as a protective mirror backing requires only a film thickness that produces negligible porosity. Thus the process may be suitably adapted to a spray application during the standard mirror production run. Deposition rates up to $127 \mu \mathrm{m} / \mathrm{hr}$ have been reported for hydrazine based chemistry operated as alkaline solutions. (10) This rate would allow the deposition of a $1000 \AA \mathrm{film}$ in less than 3 seconds and would be compatible with conventional mirror production. But, the morphology of the resulting films for very thin coatings ( $1000 \AA)$ and the suitability of the solution for either silver or copper substrates have not been reported.

Preliminary experiments have been initiated to assess the suitability of an electroless nickel film as an environmental barrier on conventional wet chemistry silvered mirrors. Key unanswered questions include: 1) morphology for thin films, 2) porosity for thin films, 3) suitability of rapid deposition rate solutions on silver or copper substrates, 4) practicality of spray-on application techniques, and 5) the environmental stability of coated mirrors.

One solution deposition technique taken from the iiterature ${ }^{(18)}$ was examined in the laboratory at PNL. The solution contained a $\mathrm{Ni}^{++}$salt, sodium hypophosphite as a reducer, and had a pH between 8 and 10 . The solution was heated to $91 \pm 5^{\circ} \mathrm{C}$. Dip treatment of silver films on glass destroyed the silver film and demonstrated no nickel film growth. No samples were tested in this solution with glass/silver/copper mirrors.

An acidic electroless nickel was obtained from MacDermid, Inc. for additional tests. The pH 5.0 solution also contains sodium hypophosphite. The recommended deposition temperature is $76-88^{\circ} \mathrm{C}$. Deposition rates cited are 10.1 and $20.2 \mu \mathrm{m} / \mathrm{hr}$ at the two temperatures respectively. This rate is 
only $220 \%$ of the maximum value noted in the 1 iterature. Dip processing of glass/silver samples resulted in delamination at the silver glass interface. Further tests are required to determine if this delamination resulted from internal film stress in the relatively thick (5-6 $\mu \mathrm{m})$ nickel layer or from chemical attack of the silver/glass interface.

The commercial solution was also used with a glass/silver/copper mirror. Silver/glass delamination again occurred for these relatively thick films, but to a lesser degree than seen for the glass/silver samples. The copper film was not pretreated with tin chloride or with palladium chloride before the nickel application.

The experiments performed in this preliminary study were far too inconclusive to make a firm recommendation on the suitability of this technology for enhancing the durability of solar mirrors. The literature which stresses their integrity and durability is very encouraging. However, examination of thinner films is necessary before a judgement can be made. Since this technology may be readily adaptable to existing mirror lines at nominal cost, it should be pursued further. 


\section{REFERENCES}

1. V. F. Burolla, S. L. Roche. 1980. Silver Deterioration in Second Surface Solar Mirrors. SAND79-8276. Sandia National Laboratories, Livermore, California.

2. M. A. Lind et al. 1979. Heliostat Mirror Survey and Analysis. PNL-3194, Pacific Northwest Laboratory, Richland, Washington.

3. M. A. Lind, Ed., Proceedings of the Second Solar Reflective Materials Workshop. 1980. In: Solar Energy Materials, Vol. 3, No. 1-2. (1980).

4. J. E. Shelby, et al. The Effect of Thermal History on the Structure of Chemically and Vapor Deposited Silver Films on Glass, SAND 79-8825, Sandia National Laboratories, Livermore, California.

5. M. Tomozawa and R. H. Doremus. 1979. Treatise on Materials Science and Technology. Vol. 17, Glass II. Academic Press, New York.

6. S. K. Sharma and J. Spitz. 1979. "Hole Growth in Thin Silver Films." Thin Solid Films, 56:L17-L19.

7. A. Brenner and C. E. Riddel. 1946. Proc. Amer. Electroplaters' Soc. 33:16.

8. A. Brenner and C. E. Riddel. 1947. Proc. Amer. Electroplaters' Soc. 34:156.

9. M. Pushpavanam and B. A. Shenoi. 1977. Electroless Nickel--A Versatile Coating. Finish. Inc., Vol. 1, No. 6, p. 48-50, 52, 58.

10. L. D. Brown and G. D. R. Jarrett. 1971. Transactions of the Institute of Metal Finishing 49:1-6.

11. N. Feldstein and T. S. Lancsek. 1971. Trans. Inst. of Met. Finish, 49:156.

12. S. L. Chow, N. E. Hedgecock, M. Schlesinger and J. Rezek. 1971.

J. Electrochem. Soc., 119:1614. 
13. J. P. Randin and H. E. Hintermann. 1967. Plating, 54:523.

14. S. T. Pai, J. P. Marton and J. Brown. 1972. J. Appl. Phys., 43:282.

15. M. Schlesinger and J. P. Marton. 1968. J. Phys. Chem. Solids, 29:188.

16. J. P. Marton and M. Schlesinger. 1968. J. Electrochem. Soc., 115:16.

17. A. H. Graham, R. W. Lindsay and H. J. Read. 1965. J. Electrochem. Soc., 112: 401 .

18. B. Scheig. 1973. Mirrors, Pelham Book, London. 


\section{DISTRIBUTION}

No. of

Copies

OFFSITE

27 Technical Information Center

B. Ackerman

Corning Glass Works

Main Plant, Bldg. 8-5

Corning, NY 14830

M. Adams

Jet Propulsion Laboratory

4800 Dak Grove Drive

Pasadena, CA 91108

J. F. Banas, 4722

Sandia Laboratories

Box 5800

A1buquerque, NM 87115

P. Bender

Ford Motor Company

Glass Division

3000 Rena issance Center

PO Box 43343

Detroit, MI 48253

M. Berry

Boeing Engr. and Const. PO Box 3707

Seattle, WA 98124

J. Bigger

Electric Power Research Institute PO Box 10412

Palo Alto, CA 93403

J. K. Blackburn

Carolina Mirror Corp.

PO Box 548, Elkin Rd.

N. Wilkesboro, NC 28659

F. Blake

Northrup, Inc., Blake Laboratory

Suite 306

7061 S. University Blvd.

Littleton, CO 80122
No. of

Copies

F. L. Bouquet

Jet Propulsion Laboratory

4800 Oak Grove Drive

Pasadena, CA 91108

G. E. Brandvold, 4713

Sandia Laboratories

Box 5800

Albuquerque, NM 87115

G. Braun

DOE Division of Solar Technology 20 Massachusetts Ave. Wasnington, DC 20545

C. J. Brinker, 5845

Sandia Laboratories

Box 5800

Albuquerque, NM 87115

T. D. Brumleve, 8451

Sandia Laboratories

Livermore, CA 94550

V. Burolla

Sandia Laboratories

Livermore, CA 94550

Ken Busche

Busche Energy Systems

7288 Murdy Circle

Huntington Beach, CA 92647

B. Butler

Solar Energy Research Institute 1536 Cole Blvd.

Golden, CO 80401

P. Call

Solar Energy Research Institute 1536 Cole Blvd.

Golden, CO 80401 
No. of

Copies

R. E. Cambron

Springborn Laboratories

Water Street

Enfield, CT 06082

W. Carroll

Jet Propulsion Laboratory

4800 Oak Grove Drive

Pasadena, CA 91108

A. A. Churm

DOE Chicago Patent Group

9800 South Cass Avenue

Argonne, IL 60439

N. H. Clark, 1415

Sandia Laboratories

Box 5800

Albuquerque, NM 87115

G. Cottingham

Brookhaven National Laboratory

Upton, NY 11973

T. Coyle

Solar Energy Research Institute

1536 Cole Bivd.

Golden, CO 80401

D. Culler

Gardner Mirror Corp.

PO Box 638, Hwy. 268E.

N. Wilkesboro, NC 28659

A. Czanderna

Solar Energy Research Institute

1536 Cole Blvd.

Golden, CO 80401

W. R. Delameter, 8451

Sandia Laboratories

Livermore, CA 94550

T. A. Dellin, 4723

Sandia Laboratories

Box 5800

Albuquerque, IM 87115
No. of

Copies

E. J. Dempsey

London Laboratories Limited

Box 3637

Woodbridge, CT 06525

R. J. Eagan, 5845

Sandia Laboratories

Box 5800

Albuquerque, NM 87115

C. R. Easton

McDonnel1 Douglas

Astronautics Co.

5307 Bolsa Ave.

Huntington Beach, CA 92647

P. J. Eicker, 8326

Sandia Laboratories

Livermore, CA 94550

S. D. Elliott

DOE San Francisco Operations Office

1333 Broadway

Wells Fargo Bldg.

Oakland, CA 94612

R. A. England

Martin Marietta

MS S0403

PO Box 179

Denver, CO 80201

H. E. Felix

Solaramics, Inc.

1301 El Segundo Blvd.

E1 Segundo, CA 90245

M. J. Fish, 8326

Sandia Laboratories

Livermore, CA 94550

C. R. Frownfelter

PPG Industries, Inc.

One Gateway Center

Pittsburg, PA 15222 
No. of

Copies

John Garate

General Electric

1 River Road

Schenectady, NY 12345

F. P. Gerstle, 5844

Sandia Laboratories

Box 5800

Albuquerque, NM 87115

R. L. Gervais

McDonnel1 Douglas Astronautics

5301 Bolsa Ave.

Huntington Beach, CA 92647

R. N. Griffin

General Electric

1 River Road

Schenectady, NY 12345

R. Gillette

MS $9 A-46$

Boeing Engr. and Const.

PO BOX 3707

Seattle, WA 98124

G. Gross

Solar Energy Research Institute 1536 Cole B1vd.

Golden, CO 80401

B. Gupta

Solar Energy Research Institute 1536 Cole Blvd.

Golden, CO 80401

M. U. Gutstein

DOE Division of Solar Technology

20 Massachusetts Avenue

Washington, DC 20545

W. Haller

Chief, Inorganic Glass Section

Institute for Materials

Research

National Bureau of Standards

Washington, DC 20234
No. of

Copies

T. R. Heaton

Martin Marietta Corporation

P. 0. Box 179

Denver, CO 80201

R. Hobbs

General Electric Company

P.0. Box 8661 - Room 7310

Philadelphia, PA 19101

P. L. Hofmann

Battelle

505 King Ave.

Columbus, $\mathrm{OH} 43201$

Richard Horton

General Electric

1 River Road

Schenectady, NY 12345

C. G. Howard

Booz, Allen \& Hamilton, Inc.

8801 E. Pleasant Valley Road

Cleveland, $\mathrm{OH} 44131$

Dennis Horgan

Solar Energy Research Institute

1536 Cole Blyd.

Golden, CO 80401

E. L. Katz

Aerospace Corporation

Solar Thermal Projects

Energy Sysiems Group

PO Box 92957

Los Angeles, CA 90009

Ernie Lam

Bechtel National Inc.

MS 50/16

P.0. Box 3965

San Francisco, CA 94119

S. Lamensdorf

Binswanger Mirror Co.

1355 Lynnfield Rd., Suite 205

PO Box 17127

Memphis, TN 38117 
No. of

Copies

C. M. Lampert

Lawrence Berkeley Laboratory

Bidg. 62, Rm 235

University of California

Berkeley, CA 94720

J. A. Leonard, 4725

Sandia Laboratories

Box 5800

Albuquerque, NM 87115

I. E. Lewis

Ford Aerospace

3939 Fabian Way

Palo Alto, CA 94303

V. L. Lindberg

Ford Glass Technical Center

25500 West Outer Drive

Lincoln Park, MI 48146

R. Livingston

Solar Energy Research Institute 1536 Cole Blvd.

Golden, CO 80401

K. Masterson

Solar Energy Research Institute

1536 Cole Blvd.

Golden, CO 80401

P. L. Mattern, 8342

Sandia Laboratories

Livermore, CA 94550

10 C. L. Mavis

Sandia Laboratories

Livermore, CA 94550

Mrs. McHugh

Sanders Associates

95 Canal St., MS MER12-1214

Nashua, NH 03061

J. Megland

PRC 1 EAC

7600 01d Springhouse Rd.

MCClaine, VA 22102
No. of

Copies

L. Melamed

DOE Division of Solar Technology

20 Massachusetts Avenue

Washington, DC 20545

B. E. Mills, 8315

Sandia Laboratories

Livermore, CA 94550

WaJter Moore

Veda, Inc.

400 N. Mobil, Bldg. D

Camarillo, CA 93010

W. L. Morehouse, 8451

Sandia Laboratories

Livermore, CA 94550

R. E. Mutzberg

PPG Industries, Inc.

1377 Oakleigh Dr.

East Point, GA 30344

E. Nelson

ACUREX Corporation

485 Clyde Avenue

Mountain View, CA 94042

H. F. Norris, Jr., 8451

Sandia Laboratories

Livermore, CA 94550

L. P. 01dhars

Martin Marietta Corp.

MS S8120

PO Box 179

Denver, CO 80201

R. Pettit, 5842

Sandia Laboratories

Box 5800

Albuquerque, AM 87115

J. A. Pietsch

Northrup, Incorporated

302 Nichols Orive

Hutchins, TX 75141 
No. of

No. of

No. of

Copies

J. Schrauth

Jena Glaswerk Schott

\& Gen., Inc.,

11 East 26th Street

New York, NY 10010

J. C. Schumacher

Schumacher \& As sociates

2550 Fair Oaks Blvd., Suite 120

Sacramento, CA 95825

Copies

R. N. Schwe inberg

DOE San Francisco Operations Office

1333 Broadway

Wells Fargo Bldg.

Oakland, CA 94612

J. Shelby

Sandia Laboratories

Livermore, CA 94550

W. Toml inson

Environmental Library

758 Eddy St.

Univ. of Montana

Missoula, MT 59812

P. Tremblay

Foster-Miller Associates

135 Second Ave.

Wal than, MA 02154

R. Turner

Falconer Plate Glass Corp.

500 S. Work Street

Falconer, NY 14733

C. N. Vittitoe, 4231

Sandia Laboratories

Box 5800

Albuquerque, NM 87115
A. F. Shoemaker
Corning Glass Works
Corning, NY 14830

10 J. Vitko

Sandia Laboratories

Livermore, CA 94550

A. C. Skinrood

R. R. Walters

Sandia Laboratories

Livermore, CA 94550

E. Systems

Energy Technology Center

PO Box 6118

D. A. Steinmeyer

McDonnell Douglas Astronautics

5301 Bolsa Avenue

Huntington Beach, CA 92647

Howard Sund

Ford Aerospace

3939 Fabian Way, T33

Palo Alto, CA 94303

Dallas, TX 75222

J. D. Walton, Jr.,

Engineering Experiment Station

Georgia Institute of Technology

Atlanta, GA 30332

R. C. Wayne, 8450

Sandia Laboratories

Livermore, CA 94550

H. R. Swift

Libby Owens Ford Company

L. Weinstein

Technical Center

1701 E. Broadway

Toledo, $\mathrm{OH} 43605$

McDonnell Douglas

Astronautics Co.

5301 Bolsa Ave.

Huntington Beach, CA 92647

John Thornton

Solar Energy Research Institute

1536 Cold B1vd.

Golden, CO 80401 
No. of

Copies

S. White, 8451

Sandia Laboratories

Livermore, CA 94550

D. Wiley

Guardian Industries Corp.

43043 W. Nine Mile Road

Northville, MI 48167

10 W. G. Wilson

Sandia Laboratories

Livermore, CA 94550

G. Yaeger

Buckmin Industries

$1485 E$. Curtis

Reedley, CA 93654

\section{FOREIGN}

T. Hisakado

SUNSHINE Project Operation Bureau 5-8-2, Marunouchi, Chiyoda-ku

Tokyo, Japan

A. K. Seth

Solar Energy Group

Centre of Energy Studies

Indian Institute of Technology

Haug Khas, New Dehli

110029 , India

T. Tanaka

Electrotechnical Laboratory

5-4-1, Mukodai, Tanashi

Tokyo, Japan
No. of

Copies

ONSITE

2 DOE Richland Operations Office

H. E. Ransom

R. Stewart

68 Pacific Northwest Laboratory

C. Q. Buckwalter

(5)

W. J. Coleman

L. S. Dake

J. L. Daniel

K. Drumheller

J. S. Hartman

M. A. Lind (50)

A. M. Sutey Publishing Coordination

Technical Information JO 